\title{
Changes in Thermotolerance of Photosynthetic Apparatus in Cucumber Leaves in Response to Water Stress and Exogenous ABA Treatments
}

\author{
Zhijun Li* ${ }^{*}$, Masayuki Oda, Kunihiko Okada and Hidekazu Sasaki \\ National Research Institute of Vegetables, Omamental Plants and Tea, Ano, Mie 514-23
}

\begin{abstract}
Summary
Effects of water stress and exogenous abscisic acid (ABA) treatments on thermotolerance of photosynthetic apparatus (PA) in cucumber (Cucumis sativus L.) leaves were investigated. Evaluation of thermotolerance was based on the heat sensitivity of photosystem II (PSII) based on chlorophyll fluorescence emission. Plants were water-stressed by either withholding water to intact plants or placing excised shoots in an open atmosphere in a glasshouse. The extent of water stress was monitored by measuring the water potential of leaves. At intervals during water stress treatment, the ratio of variable to maximum fluorescence $(\mathrm{Fv} / \mathrm{Fm})$ of leaves was determined. Immediately after that, the leaves were dipped in a water bath held at $45{ }^{\circ} \mathrm{C}$ for $10 \mathrm{~min}$ and $\mathrm{Fv} / \mathrm{Fm}$ values were determined again. Percentages of $\mathrm{Fv} / \mathrm{Fm}$ values remaining after the heat treatment were used as a measure of thermotolerance of PA. With intact plants, thermotolerance of PA increased significantly when the leaf water potential was decreased to - $1.0 \mathrm{MPa}$; it attained maximum at -1.5 to $-2.0 \mathrm{MPa}$. However, the thermotolerance decreased when water potential was further lowered to $-4.0 \mathrm{MPa}$. Leaves of excised shoots showed similar changes in thermotolerance of PA in response to the decrease in water potential, except that the maximum tolerance was obtained at $-0.8 \mathrm{MPa}$. When intact plants were reirrigated after 3 days of water stress treatment, the thermotolerance of PA increased temporarily during the first $2 \mathrm{hr}$, and then decreased sharply within $24 \mathrm{hr}$ to the level of the irrigated control plant leaves. Exogenous ABA applied to leaves of irrigated plants caused an increase in thermotolerance of PA depending on its concentrations. Leaves treated with $1.00 \mathrm{mM} \mathrm{ABA}$ showed nearly complete tolerance of PA within a day; this high tolerance level was maintained for at least 6 days. Leaves treated with 0.01 to $0.25 \mathrm{mM}$ $A B A$ reached a peak tolerance after a day and then lost much of the ABA-induced thermotolerance after 3 days. The results indicate that the enhanced thermotolerance of $P A$ in water-stressed cucumber leaves was probably mediated through a water-stress-induced increase in endogenous levels of ABA.
\end{abstract}

\section{Introduction}

Under high temperature conditions, plants are usually exposed not only to heat stress but also to water stress. Water deficit in plant tissues may cause an increase in leaf temperature due to de creased transpiration. For this reason, water stressed plants exhibit more severe injury on leaves when exposed to high air temperature (Oda et al., 1993). However, water stress that occurs prior to

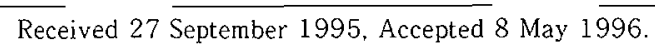

* Present address: Graduate School of Bioresources, Mie University, Tsu, Mie 514, Japan. high temperature stress has been reported to induce thermotolerance in maize leaves (BonhamSmith et al., 1987). We also found that drought treatment before high temperature exposure increased thermotolerance of cucumber leaves (unpublished). In addition, water stress can induce chilling and freezing tolerances in many plant species (Utsunomiya, 1988). It appears that there is a common water-stress-related physiological mechanism by which the plants survive exposure to these stresses.

In general, plants accumulate abscisic acid (ABA) when exposed to stressful environments including 
drought (Cornic and Zeevaart, 1984), chilling (Chen et al., 1983), high temperature (Abass and Rajashekar, 1.993), salinity (Talanova and Titov, 1994), and flooding (Zhang and Zhang, 1994). Furthermore, application of exogenous ABA enhances plant tolerance to various stresses (Robertson et al., 1994; Chen and Gusta, 1983). Based on these results, $A B A$ is regarded as a general endogenous inducer of tolerance to environmental stresses (Mantyla et al., 1995).

Heat stress, depending on the temperature and duration, affects numerous physiological processes in plants. Moderately elevated temperatures diminish photosynthetic activities, accelerate senescence, and disturb respiration and movements of water and ion in cells (Camp et al., 1982). Extremely high temperatures can cause proteins to denature and degrade and disrupt cell membrane functions, e.g. leakage of cytoplasmic solutes. Photosynthetic apparatus (PA) is the primary target of high temperature stress (Berry and Bjorkman, 1980; Volger and Santarius, 1981). Photosystem II (PSII) reaction centers are very sensitive to heat and the activity of electron transport through them is inhibited at relatively moderate temperatures (Havaux. 1993). Although water stress can directly affect photosynthetic activity, PSII is not sensitive to water deficit (Cornic and Briantais, 1991). Results of He et al. (1995) show that water stress declined the steady state levels of major PSII proteins, but did not affect electron donation to PSII. It seems possible that the alteration in protein metabolism in PA or cells by water stress changes the heat sensitivity of the PA. However, there is no direct evidence in the literature on the thermal response of PA in water-stressed leaves and whether the thermotolerance of PA is controlled by ABA.

In the present study, we investigated the effects of water stress and exogenous ABA treatments on thermotolerance of PA in cucumber leaves. Evaluation of thermotolerance was based on chlorophyll fluorescence measurement, which has been shown as a reliable, rapid and non-destructive for detecting heat stress damage to PA or PSII (Smillie and Hetherington, 1983).

\section{Materials and Methods}

\section{Experiment 1}

Seeds of cucumber (Cucumis sativus L.) cv.
Nankyoku No. 2 were germinated on moist filter paper at $28{ }^{\circ} \mathrm{C}$ for a day. The seedlings were then planted individually in $350 \mathrm{ml}$ plastic pots containing a mixture of bark compost and soil $(1: 3$, $\mathrm{v} / \mathrm{v}$ ), and grown in a glasshouse kept at a max. imum of $31.2 \pm 3.2{ }^{\circ} \mathrm{C}$ (Tmax) and a minimum of $14.4 \pm 1.4{ }^{\circ} \mathrm{C}(\mathrm{Tmin})$, with a mean solar radiation (SR) of $10.3 \pm 5.8 \mathrm{MJ} / \mathrm{m}^{2} /$ day during March to May. Four weeks after planting, plants with 3 fully expanded leaves were water-stressed by withholding water $(0 \mathrm{ml} /$ plant/day). Control plants were thoroughly irrigated daily (75-100 $\mathrm{ml} /$ plant/day). Chlorophyll fluorescence and water potential of leaves were measured by the methods as described below; at 1 -day intervals for waterstressed plants and at 2-day intervals for control plants after treatment. Four plants were used per measurement.

\section{Experiment 2}

Plants were grown as in Experiment 1 . Seven weeks after planting, roots of plants with 6 fully expanded leaves were excised below cotyledons and the shoots were water-stressed by placing them in the glasshouse to dehydrate. Chlorophyll fluorescence and water potential of the leaves of excised shoots were measured at $0,2,4,6,8,24$, and $48 \mathrm{hr}$ after excision. Each measurement was made on three shoots.

\section{Experiment 3}

Plants were grown as in Experiment 1 during July to August in a glasshouse kept at $40.9 \pm 2.9$ ${ }^{\circ} \mathrm{C}$ Tmax and $25.1 \pm 1.0^{\circ} \mathrm{C}$ Tmin, with SR of 10.9 $\pm 5.6 \mathrm{MJ} / \mathrm{m}^{2} /$ day. Three weeks after planting, plants with 3 fully expanded leaves were waterstressed for 3 days as in Experiment 1, and then well-irrigated daily. Chlorophyll fluorescence and water potential of leaves were measured at $0,2,4$, $6,8,24,48$, and $72 \mathrm{hr}$ after re-irrigation. Four plants were used per measurement.

\section{Experiment 4}

Plants were grown as in Experiment 3. Five weeks after planting, whole leaves of well-irrigated plants with 4 fully expanded leaves were sprayed with about $70 \mathrm{ml}$ aqueous solution of (+). s-ABA at concentrations of 0 (control), 0.01, 0.05, 0.25 , and $1.00 \mathrm{mM}$. Chlorophyll fluorescence of leaves was measured $0,1,3$, and 6 days after 
ABA application. Three plants were used for each measurement.

\section{Measurement of chlorophyll fluorescence.}

Fluorescence was measured on the second expanded leaves (the third leaves were used in Experiment 3) with a fluorometer (SF-20, Richard Branker Research Ltd. Ottawa, Canada). After the fluorescence measurement, all leaves of intact plants or derooted shoots were subjected to heat stress by dipping them for $10 \mathrm{~min}$ in water bath held at $45{ }^{\circ} \mathrm{C}$. Afterwards, fluorescence of the same leaf was again measured. The values of Fo, constant yield, and Fm, maximal yield of fluorescence were provided by the fluorometer, and $\mathrm{Fv} / \mathrm{Fm}$ value was obtained according to the formula of (Fm-Fo)/Fm. The percentage of $\mathrm{Fv} / \mathrm{Fm}$ values remaining after the heat stress treatment was calculated as an indicator of thermotolerance of PA.

To determine the effect of water absorption by leaves during heat stress on chlorophyll fluorescence emission, detached leaves either sealed in thin polyvinylidene chloride film or unsealed were dipped in a water bath at $45^{\circ} \mathrm{C}$ for $10 \mathrm{~min}$. Unsealed leaves absorbed water and thus had higher water potential than did sealed leaves (Table 1 ). However, $\mathrm{Fv} / \mathrm{Fm}$ values of unsealed leaves did not differ from those of sealed leaves. The results indicate that water absorption by leaves during the 10-min heat stress treatment exerted little influ- ence on chlorophyll fluorescence. Therefore, for the convenience of operation, unsealed leaves were used for heat stress treatment in subsequent experiments.

\section{Measurement of leaf water potential}

Leaf discs of about $12 \mathrm{~cm}^{2}$ area were cut with a razor blade from leaves on the same leaf position as those for chlorophyll fluorescence measurement. Water potential of leaves before heat stress treat. ment was measured with a thermocouple psychrometer (HR-33T, Wescor Inc., Logan USA) connected to a $X Y$ recorder (SS $100 \mathrm{~F}$ MM, Sekonic, Tokyo Japan). Three or four leaves were used per measurement.

\section{Results}

\section{Exp. 1. Changes in thermotolerance of $P A$ in plants water-stressed by withholding water}

Leaves wilted slightly after 1 day of withholding water but severely after 6 days. The leaves recovered turgor during the night for the first 4 days of water stress. Thermotolerance of PA in the treated leaves gradually increased within 6 days, as evidenced by higher $F v / F m$ values than those of the control leaves (Fig. 1). A rapid increase in the tolerance occurred after 6 days of water stress treatment when leaf water potential fell below $-1.0 \mathrm{MPa}$. The maximum thermotolerance was attained at -1.5 to $-2.0 \mathrm{MPa}$, but

Table 1. Effect of sealing the detached leaves with plastic film during heat stress treatment on their water content, water potential and Fv/Fm values after heat stress treatment. Leaves were detached from plants, water-stressed by withholding irrigation, sealed or unsealed with polyvinyldene chloride film, and then dipped for $10 \mathrm{~min}$ in a $45^{\circ} \mathrm{C}$ water bath.

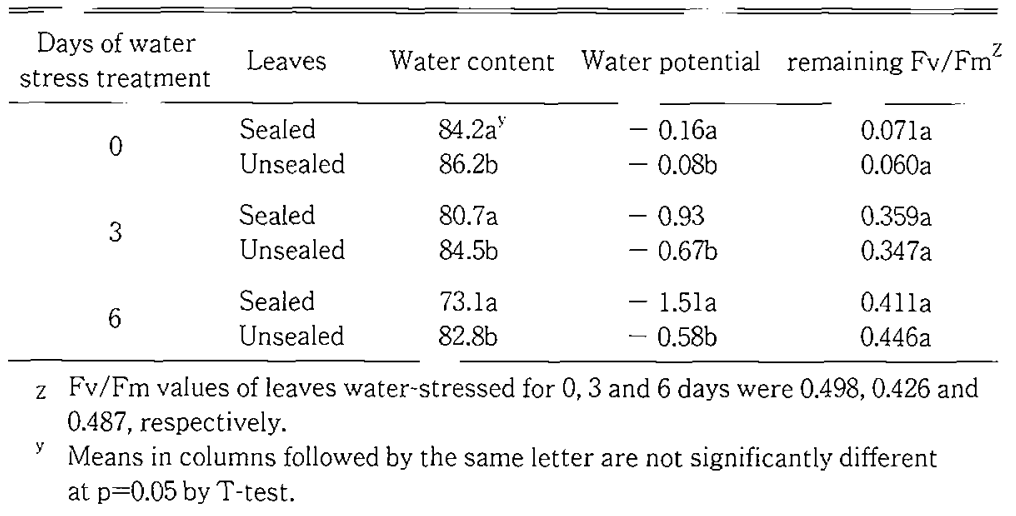


when leaf water potential was lowered to -4.0 $\mathrm{MPa}$, thermotolerance decreased (Fig. 1, inset). Thermotolerance of PA of control leaves changed slightly during experimental period.

\section{Exp. 2. Changes in thermotolerance of PA in leaves of excised shoots with increasing loss of water}

When the excised shoots were placed in an open atmosphere, the leaves lost turgor within several minutes. Thermotolerance of PA in these leaves increased rapidly corresponding to the decrease in water potential (Fig. 2). A slight rise in water potential $8 \mathrm{hr}$ after shoot excision, which was probably caused by absorption of water vapor from the atomosphere after sunset, resulted in a slight reduction in thermotolerance. The relationship between the decrease in water potential and
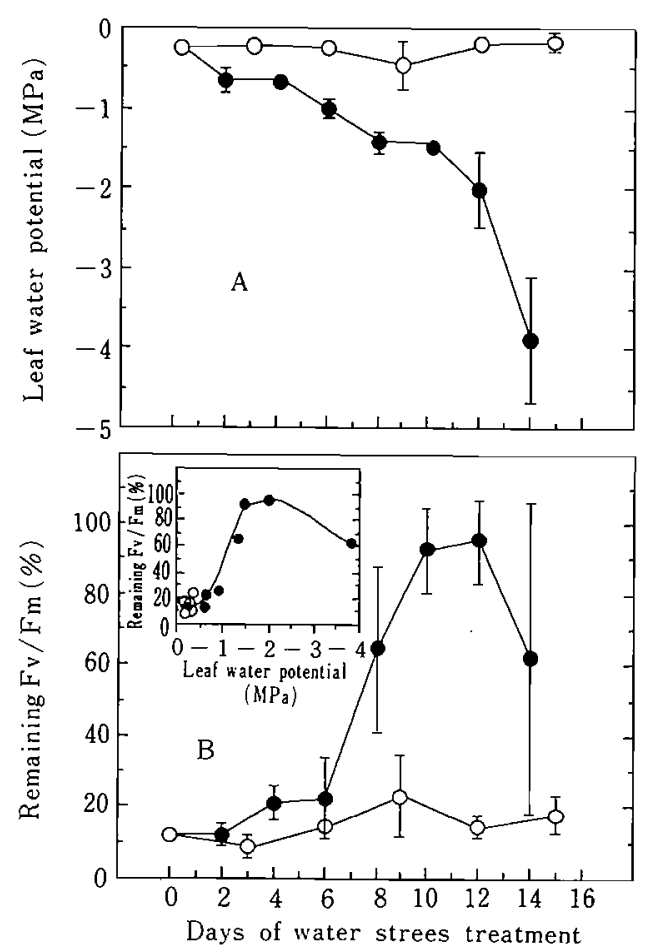

Fig. 1. Changes in leaf water potential (A) and thermotolerance of PA as evaluated by the percentage of $\mathrm{Fv} / \mathrm{Fm}$ remaining after heat stress treatment $(\mathrm{B})$ in intact water-stressed $(O)$ and control $(O)$ cucumber plants. The inset shows the relationship between the leaf water potential and percentages of remaining $\mathrm{Fv} / \mathrm{Fm}$. Vertical bars show the standard error of means of four replications. the increase in thermotolerance was approximately linear until water potential was lowered to -0.8 $\mathrm{MPa}$. When the water potential of leaves was decreased to -0.8 to $-1.2 \mathrm{MPa}$, little damage to PA occurred from the 10 -min heat treatment at $45{ }^{\circ} \mathrm{C}$ (Fig. 2, inset).

\section{Exp. 3. Changes in thermotolerance of $P A$ during re- covery of leaves from water stress}

When plants were water-stressed for 3 days, leaves wilted moderately during the day-time, and water potential of the leaves was lowered to -1.0 $\mathrm{MPa}$ by the end of the water stress treatment (Fig. $3 \mathrm{~A}$ ). Leaf water potential of the water-stressed plants increased rapidly during the first $6 \mathrm{hr}$ of re-irrigation, and attaining the level of the control plants after $24 \mathrm{hr}$. Leaves recovered turgor within
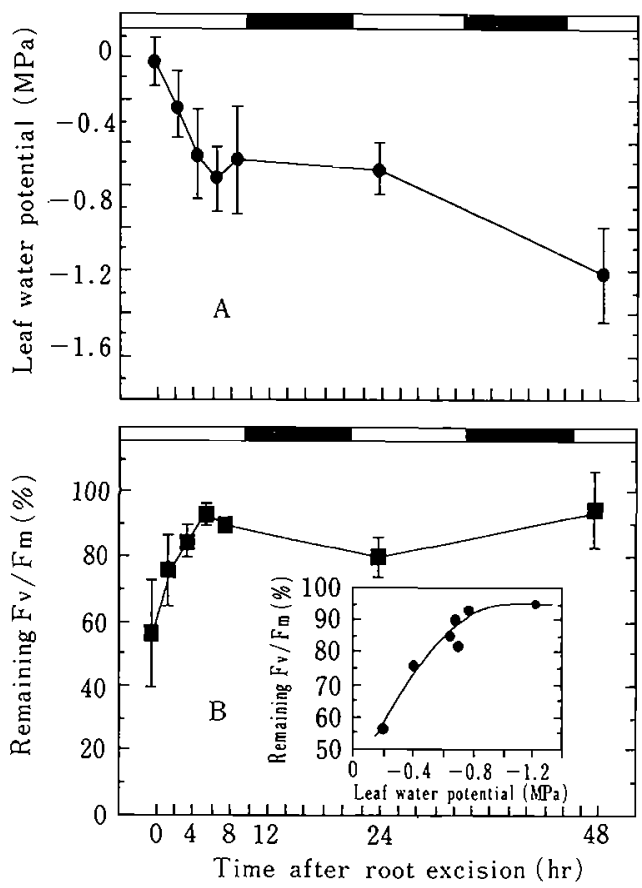

Fig. 2. Changes after water stress in leaf water potential (A) and thermotolerance of PA as evaluated by the percentage of $\mathrm{Fv} / \mathrm{Fm}$ remaining after heat stress treatment $(B)$ in excised cucumber shoots. The inset shows the relationship between the leaf water potential and percentages of remaining $\mathrm{F}_{\mathrm{V}} / \mathrm{Fm}$. Horizontal bars indicate the day ( $\square$ ) and night ( ) Vertical bars show the standard error of means of three replications. 
$6 \mathrm{hr}$ after start of re-irrigation, exhibiting no sign of wilting thereafter, even though the leaf water potential was slightly but significantly lower than that of the control plants from $24 \mathrm{hr}$ onward.

Thermotolerance of PA in water-stressed leaves increased temporarily during the first $2 \mathrm{hr}$, and then decreased rapidly to the level of the control plants within $24 \mathrm{hr}$ (Fig. 3B). The almost complete loss of water-stress-induced thermotolerance occurred when water potential was increased to $0.5 \mathrm{MPa}$, at which time the leaves had become fully turgid (Fig. 3 , inset).

Exp. 4. Changes in thermotolerance of $P A$ with ap. plication of exogenous $A B A$ to leaves

Exogenous ABA applied to leaves caused an increase in thermotolerance of PA in the leaves (Fig.
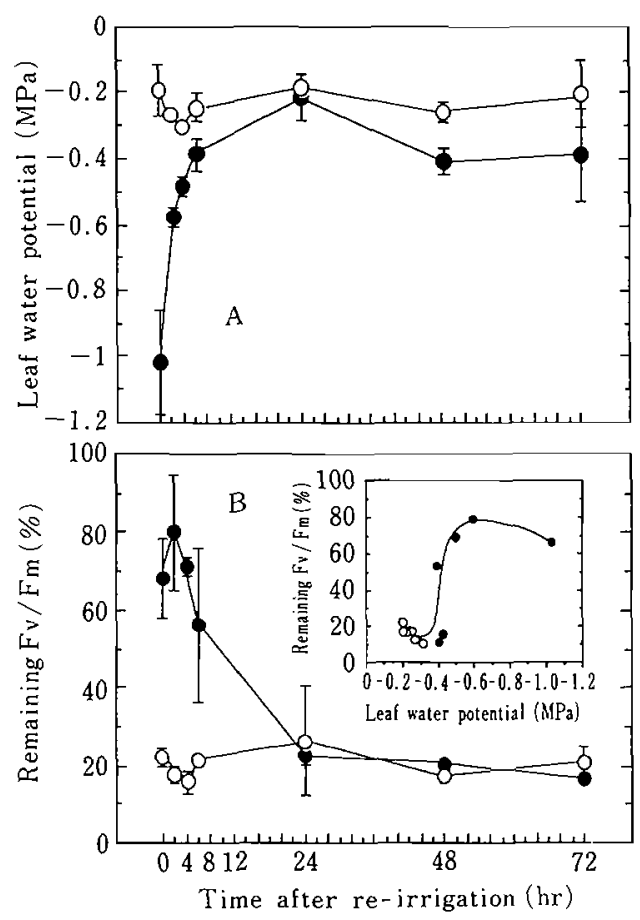

Fig. 3. Changes during recovery from water stress in leaf water potential (A) and thermotolerance of $\mathrm{PA}$ as evaluated by the percentage of $\mathrm{Fv} / \mathrm{Fm}$ remaining after heat stress treatment $(B)$ in intact water-stressed $(O)$ and control $(O)$ cucumber plants. The inset shows the relationship between the leaf water potential and percentages of remaining $\mathrm{Fv} / \mathrm{Fm}$. Vertical bars show the standard error of means of four replications.
4). The extent of the increase was dependent on the concentration of $A B A$. Leaves treated with $1.00 \mathrm{mM} \mathrm{ABA}$ showed nearly complete tolerance of PA at day 1 and maintained this high tolerance for at least 6 days. However, leaves sprayed with lower concentrations of ABA showed a decrease in tolerance of PA at day 3 after the peak tolerance was attained at day 1 . Leaves treated with 0.01 to $0.05 \mathrm{mM} \mathrm{ABA}$ lost $\mathrm{ABA}$-induced thermotolerance of PA almost completely at day 3 .

\section{Discussion}

In the present study, heat stress damage to PA in leaves was evaluated on the basis of $\mathrm{Fv} / \mathrm{Fm}$ values of chlorophyll fluorescence emission. The decrease in $\mathrm{Fv} / \mathrm{Fm}$ is directly correlated with loss of PSII activity of thylakoid membranes and thus a good indicator of heat damage to PA (Berry and Bjorkman, 1980). The results of the present study demonstrated clearly that thermotolerance of PA in cucumber leaves was significantly enhanced in response to water stress treatment. Development of thermotolerance as well as its loss was very rapid as evidenced in that the tolerance was induced within several hours of water stress in leaves of excised shoots (Fig. 2), and the tolerance acquired during the 3 -day water stress treatment was completely lost within 1 day of recovery from water stress (Fig. 3). This rapid response leads us to postulate that water stress plays a role in heat

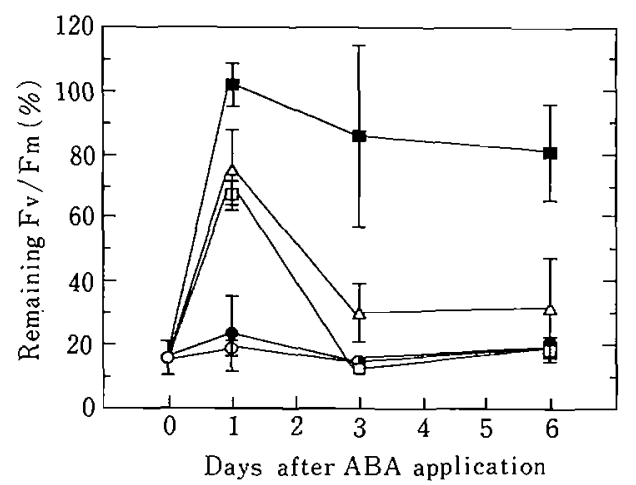

Fig. 4. Effects of foliar sprays of $0(\mathrm{O}), 0.01$ $0.05([]) .0 .25(\Delta)$ and $1.00(\square) \mathrm{mM} \mathrm{ABA}$ on thermotolerance of $\mathrm{PA}$ as evaluated by the percentage of $\mathrm{Fv} / \mathrm{Fm}$ remaining after heat stress treatment. Vertical bars show the standard error of means of three replications. 
acclimation in cucumber leaves, since acclimation of plants to heat stress is usually very rapid (Chen et al., 1982; Donald and Jerome, 1991).

Acquisition of thermotolerance of PA by waterstressed leaves was apparently related directly to the decrease in the leaf water potential. However, the response of leaves on water-stressed intact plants was not sensitive to a decrease in leaf water potential as compared to that on excised shoots; water potential of about $-1.0 \mathrm{MPa}$ resulted in only a small increase in thermotolerance of PA in the former plants, but the maximum tolerance was induced at $-0.8 \mathrm{MPa}$ in the latter (Compare Fig. 1 and 2, insets). Water-stressed intact plants regained turgor during the night because of reduced transpiration and increased water absorption from the soil and humid air. This may have partially canceled the heat-acclimating processes acquired by leaves during the day; thermotolerance of PA induced by water stress was lost very rapidly with re-irrigation as shown in Experiment 3 (Fig. 3).

There is a considerable amount of evidence that the level of ABA in plants increases with increasing water deficit (Hartung and Davies, 1991). The response of $\mathrm{ABA}$ synthesis to water status of plants is very rapid; $A B A$ accumulates in plants within several hours of water deficit (Walton et al., 1976), but is metabolized very rapidly upon rehydration (Vernieri et al., 1994). In the present study, thermotolerance of PA in cucumber leaves changed rapidly in response to increases in water deficit and rehydration in a quite similar manner to the endogenous $A B A$ levels as described above. In addition, exogenous $A B A$ was effective in inducing thermotolerance in cucumber leaves and the induction of thermotolerance by $\mathrm{ABA}$ was dependent on its concentrations (Fig. 4). That the effect of exogenous ABA was only temporary at lower concentrations may be partly attributed to the rapid metabolism of the compound in turgid leaves (Zeevaart and Boyer, 1984). Although we obtained no direct evidence that endogenous ABA is involved in heat acclimation by water stress, the results in this study suggest that acquisition of thermotolerance of PA by water-stressed cucumber leaves was mediated through the increased levels of endogenous ABA in leaves.

Heat stress injury in leaves often accompanies desiccation stress injury because of increased loss by transpiration (Treshow, 1970). In this case, exogenous ABA may enhance thermotolerance of leaves by causing stomatal closure and thus ameliorating water loss (Jones and Mansfield, 1970; Takahashi et al., 1993). In this study, however, leaves did not become desiccated during heat stress because the heat treatment involved dipping unsealed leaves in hot water. Consequently, the enhanced thermotolerance of PA in cucumber leaves by exogenous $\mathrm{ABA}$ and water stress probably resulted from their direct or indirect action to the $\mathrm{PA}$. As Fv/Fm reflects the state of thylakoid membrane and its decrease has been suggested to correlate with damage or inhibition of PSII or closely to their reaction centers (Krause and Santarius, 1975; Pearcy et al., 1977). Heat stress may produce conformational changes in PSII proteins resulting in their denaturation, polypetide chain unfolding and coagulation. Since water stress and $A B A$ are known to induce the accumulation of heat-stable proteins called dehydrins (Close et al., 1989; Jacobsen and Shaw, 1989), it seems possible that water stress and exogenous ABA confer heat tolerance of the thylakoid membrane proteins. Further studies are needed to elucidate the phy. siological bases of thermotolerance induction in $\mathrm{PA}$ by water stress and exogenous $\mathrm{ABA}$.

\section{Acknowledgement}

We are indebted to Professor Dr. S. Tachibana, Mie university for his critical reading of this manuscript. This study was partly supported by the Science and Technology Agency (STA).

\section{Literature Cited}

Abass, M. and C. B. Rajashekar. 1993. Abscisic acid accumulation in leaves and cultured cells during heat acclimation in grapes. HortScience $1: 50-52$.

Berry, J. A. and O. Bjorkman. 1980. Photosynthetic response and adaptation to temperature in higher plants. Annu. Rev. Plant Physiol. 31 : 391-543.

Bonham-Smith, P. C., M. Kapoor and J. D. Bewley. 1987. Establishment of thermotolerance in maize by exposure to stresses other than a heat shock does not require heat shock protein synthesis. Plant Physiol. 85 : 575-580.

Camp, P. J., S. C. Huber, J. J. Burke and D. E. Moreland. 1982. Biochemical changes that occur during senescence of wheat leaves. I. Basis for the reduction of photosynthesis. Plant Physiol. 70: 1641-1646.

Chen, H. H., Z. Shen and P. H. Li. 1982. Adaptability 
of crop plants to high temperature stress. Crop Science $22: 719-725$.

Chen, H. H., P. H. Li and M. L. Brenner. 1983. Involvement of abscisic acid in potato cold acclimation. Plant Physiol. 71 : 362-365.

Chen, T. H. H. and L. V. Gusta. 1983. Abscisic acid-induced freezing resistance in cultured plant. Plant Physiol. $73: 71-75$.

Close, T. J., A. A. Kortt and P. M. Chandler. 1989. A CDNA-based comparison of dehydration-induced proteins (dehydrins) in barley and corn. Plant Molec. Biol. 13 : 95-108.

Cornic, G. and J. A. D. Zeevaart. 1984. Abscisic acid metabolism in relation to water stress and leaf age in Xanthium strumarium. Plant Physiol. 76 : 1029-1035

Cornic, G. and J. M. Briantais. 1991. Partitioning of photosynthetic electron flow between $\mathrm{CO}_{2}$ reduction in a $\mathrm{C}_{3}$ leaf (Phaseolus vulgaris L.) at different $\mathrm{CO}_{2}$ concentrations and during drought stress. Planta 183: 178-184.

Donald, R. G. and C. S. Jerome. 1991. Carbon allocation and response to stress, p. 107-110. In : A M. Harold, E. W. William and J. P. Eva (eds.). Responses of plants to multiple stresses. Academic press, San Diego, California.

Hartung, W. and W. J. Davies. 1991. Drought-induced changes in physiology and ABA. p. 63-79. In : W. J. Davies and H. G. Jones (eds.). Abscisic acid. Physiology and Biochemistry. Bios Sci. Pub., UK.

Havaux, M. 1993. Characterization of thermal damage to the photosynthetic electron transport system in potato leaves. Plant Science $94: 19-33$.

He, J. X., J. Wang and H. G. Liang. 1995. Effects of water stress on photochemical function and protein metabolism of photosystem II in wheat leaves. Physiol. Plant. 93 : 771-777.

Jacobsen, J. V. and D. C. Shaw. 1989. Heat-stable proteins and abscisic acid action in barley aleurone cells. Plant Physiol. 91 : 1520-1526.

Jones, R. J. and T. A. Mansfeild. 1970. Suppression of stomatal opening in leaves with abscisic acid. J. Exp. Bot. $21: 714-719$.

Krause, G. H. and K. A. Santarius. 1975. Relative thermostability of the chloroplast envelope. Planta $127: 285-299$

Mantyla, E., V. Lang and E. T. Palva. 1995. Role of abscisic acid in drought-induced freezing tolerance, cold acclimation, and accumulation of LT178 and RAB18 proteins in Arabidopsis thaliana. Plant Physiol. 107: 141-148.

Oda, M., Z. Li, K. Tsuji, K. Ichimura and H. Sasaki. 1993. Effects of humidity and soil moisture content on chlorophyll fluorescence of cucumber seedlings. J. Japan. Soc. Hort. Sci. 62 : 399-405. (In Japanese with English summary).

Pearcy, R. W., J. A. Berry and D. C. Fork. 1977. Effects of growth temperature on the thermal stability of the photosynthetic apparatus of Atriplex lentiformis (Torr.) Wats. Plant Physiol. 59 : 873-878.

Robertson, A. J., M. Ishikawa and L. V. Gusta. 1994. Abscisic acid-induced heat tolerance in Bromus inermis Leyss cell-suspension cultures. Heat-stable, abscisic acid-responsive polypetides in combination with sucrose confer enhanced thermostability. Plant Physiol. 105 : 181-190.

Smillie, R. M. and S. E. Hetherington. 1983. Stress tolerance and stress-induced injury in crop plants measured by chlorophyll fluorescence In Vivo: Chilling, freezing, ice cover, heat, and high light. Plant Physiol. 72 : 1043-1050.

Takahashi, H., K. Koshio and Y. Ota 1993. Effects of ABA application to the culture solution on the growth, water relations and temperature stress in tomato plants. J. Japan. Soc. Hort. Sci. 62 : 389-397. (In Japanese with English summary).

Talanova, V. V. and A. F. Titov. 1994. Endogenous abscisic acid content in cucumber leaves under the influence of unfavourable temperatures and salinity. J. Exp. Bot. 276 : 1031-1033.

Treshow, M. 1970. Environment and plant responses. p. 66-75. McGraw-Hill, Inc. Maple press. New York.

Utsunomiya, N. 1988. Increase in cold hardiness induced by water stress in young Psidiums seedlings. J. Japan. Soc. Hort. Sci. 1 : 28-33.

Vernieri, P., A. Pardossi, G. Serra and F. Tognoni. 1994. Changes in abscisic acid and its glucose ester in Phaseolus vulgaris L. during chilling and water stress. Plant Growth Regulation 15 : $157-163$.

Volger, H. and K. A. Santarius. 1981 Release of membrane proteins in relation to heat injury of spinach chloroplasts. Physiol. Plant. 51 : 195-200.

Walton, D., M. A. Harrison and P. Cote. 1976. The effects of water stress on abscisic acid levels and metabolism in roots of Phaseolus vulgaris L. and other plants. Planta 131: 141-144

Zeevaart, J. A. D. and G. L. Boyer. 1984. Accumulation and transport of abscisic acid and its metabolites in Ricinus and Xanthizm. Plant Physiol. 74 : 934-939

Zhang, J. and X. Zhang. 1994. Can early wilting of old leaves account for much of the ABA accumulation in flooded pea plants? J. Exp. Bot. 278 : $1335-1342$. 
水ストレスおよび外生 ABA によるキュウリ葉における光合成器官の高温耐性の変化

李 智軍・小田雅行・阔田邦彦・佐々木英和

野菜茶業試験場 514-23 三重県安芸郡安䟴町

摘要

キュウリ葉の光合成器官の高温耐性に及ぼす水スト レス抢よび外生 ABAの影響を調べた。水ストレス処 理としては，灌水を停止して無傢苗に水ストレスを与 えるか，子葉下端で切断した断根苗をがラス室で自然 に脱水させるかのいずれかの方法によった：高温処理

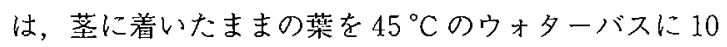
分間漫滇して行った。水ストレスは葉の水ポテンシャ ルにより, また, 光合成器官の高温耐性は高温処理後 の葉緑素蛍光相対値 $(\mathrm{Fv} / \mathrm{Fm})$ によってそれぞれ評 価した。

無傷苗では, 葉の光合成器官の高温耐性は, 水ポテ ンシャルがー1.0 MPa 以下に低下すると著しく増大し， 約 $-1.5 \sim-2.0 \mathrm{MPa}$ で最大になった。断根苗でも無 傷苗と同様に, 光合成器官の高温耐性は水ポテンシャ ルの低下につれて增大し， $-0.8 \mathrm{MPa}$ で最大となった．
3 日間断水により水ポテンシャルがー $1.0 \mathrm{MPa} に な$ った無伤苗に再雚水すると, 葉の水ポテンシャルは 24 時間以内に当初からー0.2 MPa を示した対照のレ ベルへ急激に上昇した。しかし，葉の光合成器官の高 温耐性は再灌水後 2 時間のうちに一時増大し，その後 対照のレベルまで急に低下した。外生 ABA は光合成 器官の高温耐性を高め，浱度が高いほど効果が大きか った。1.00 mMの ABAでは，処理 1 日後に当初の 5 倍の高温耐性が得られ，この高い耐性は少なくとも6 日間維持された。低濃度（0.01と $0.25 \mathrm{mM}$ )の ABA では, キュウリ葉の光合成器官の高温耐性は処理 1 日 後に最大值に達したが, 処理 3 日㣪には当初のレベル まで低下した。以上の結果から，水ストレスによるキ ュウリ葉の光合成器官の高温耐性の増大は, 葉での内 生 $\mathrm{ABA}$ の蓄積によると考えられる。 